\title{
PIONEER JOURNALISTS OF IOWA
}

\section{By John R. Adney}

In the annals of Iowa journalism there probably are no more colorful characters than the editors of pioneer days. Few pioneers surpassed the newspaper editors as trail blazers on the American frontier; the successful editor and publisher helped determine to'v sites, led in community affairs, and was the self-appointed guardian of the political, social, spiritual and cultural growth of his neighborhood.

Newspapers reflect the interests, attitudes, and activities of people and the times in which they live, and the pioneer editor' writings reveal a great deal about life in Iowa at that time. Wire photos, comics, glaring headlines, sports news, society pages, and stock market reports were absent from the pages of their papers. Yet those newspapers served as a "mirror" of those times just as present day papers reflect our society for "an adequate history of any people can scarcely be written without an examination of its journalism."

The basis for this paper is an account written in 1868 by an itinerant printer who was employed on some of the Iowa newspapers of that time. I am indebted to Dr. William Petersen, Superintendent, State Historical Society of Iowa, for permission to use information from several historical society publications.

The honor of establishing the first newspaper in Des Moines must be given to Barlow Granger, a New Yorker, who had set type with Horace Greeley and who had followed that editor's advice-"Go West, Young Man, Go West."

When Granger arrived at Fort Des Moines he found it a rought, unkempt village on the very edge of civilization. It would take courage and resourcefulness to establish a successful newspaper at this frontier outpost, but he had the qualities necessary for such an enterprise. Granger began setting type for his newspaper on July 26, 1849, in a log cabin not far from the junction of the Raccoon and Des Moines Rivers. He 
had decided to call his newspaper the Fort Des Moines Star but he found that there were not enough letters in the type box to set the title, so he emptied the type back into the box and started over. This time he set a shorter name, The Iowa Star. The change in title was prophetic of things to come as the publication became a newspaper of all Iowa, not of Fort Des Moines alone.

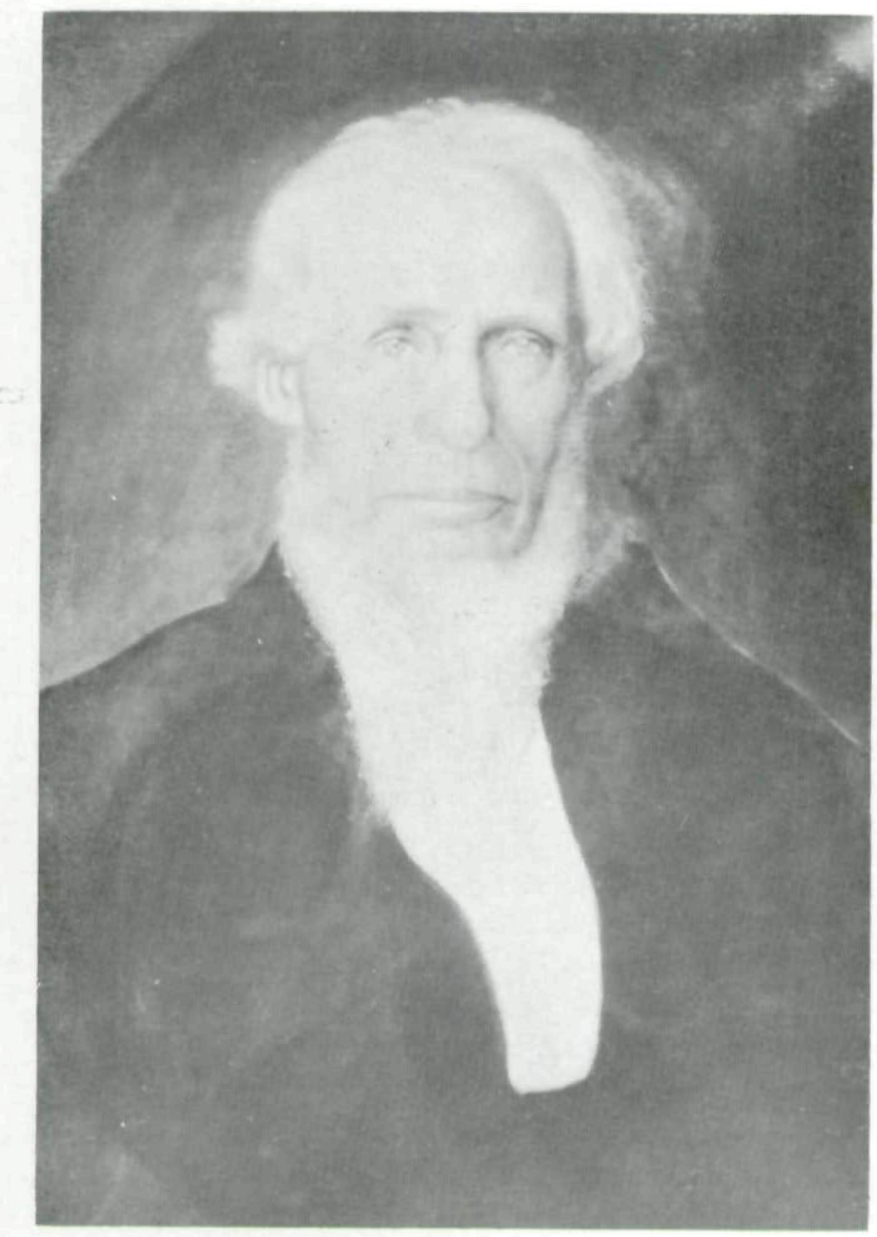

Barlow Granger 
The Star came into being when only a few hundred copies of the four-page paper were printed. In the opening issue, Granger announced that he would do everything in his power to advertise Iowa, "the heart of the most attractive country in the world." Granger had several goals for his newspaper; he and his financial backer, Curtis Bates, wanted to elect Democrats to office, they wanted more settlers to come to central Iowa and they wanted to keep those already here from hurrying off to California to dig gold. They worked to bring railroads to the state and they promoted expanded steamboat service from Keokuk up the Des Moines River, and supported transfer of the state capitol from Iowa City to Des Moines.

The Granger issues of the Star were not overloaded with news. The editor was printer, press-foreman, advertising salesman, subscription solicitor-the whole staff. The Star printed many poems, and long reports were carried on Democratic conventions, and on speeches given by prominent Democrats.

Editors pulled no punches when dealing with their opponents in those days. When Lampson Sherman started the Fort Des Moines Gazette, a Whig paper, on January 14, 1850, the Star wrote: "We wish the adventurous proprietor success in everything but the extension of his political beliefs."

Bates became editor of the Star after Granger retired and kept the paper going for four years by continuing his law practice and using his law fees to pay part of the expenses of the Star. In 1854, Bates gave up and the Star was taken over by S. W. Hill and Company, with D. O. Finch as editor. The paper continued to be unprofitable and the final issue was published on August 17, 1854.

\section{First lowa Newspaper}

The first issue of the DuBuque Visitor, the first Iowa newspaper, appeared on May 11, 1836, at DuBuque (Lead Mines), Wisconsin Territory, under the editorship of John King and Andrew Keesecker.

King was born in Shepherdstown, Virginia, in 1803 and moved to Chillicothe, Ohio, in 1829. Four years later his urge to "go West" became so strong that he set out on horseback, reaching Dubuque in September, 1833, with barely three dollars in his pocket. He found employment in the lead mines 
nearby and soon afterward formed a partnership with Alexander George, an experienced miner. He left the mines within a short time and was appointed Chief Justice of Dubuque County.

By the fall of 1835 Dubuque had a church, stores, taverns, saloons and scores of log cabins, but no newspaper. King felt the need of a newspaper in the growing community and, before the close of navigation that year, he set out for Cincinnati where he bought a Smith hand press. This press, invented in 1822 , was far superior to any which had been used before. It had a cast iron frame and the inventor had improved the machine by substituting a "toggle joint" instead of the characteristic screw and levers.

On March 31, 1836, King contracted with William C. Jones of Chillicothe, Ohio, to be employed as foreman in the printing office. He agreed to pay Jones the sum of $\$ 350, \$ 50$ to be paid at once and the balance in sums on demand; he further agreed "to provide Jones with suitable board and lodging for one year, from and after the 20th day of April, in consideration that Jones go to the town of Dubuque in Michigan territory and faithfully perform the duties of foreman in the printing office, and such other duties in superintending the publication of the newspaper as may be required."

They set up their printing shop in a two-story log cabin which had been erected by Pascal Mallet in 1834 for a residence. While Jones busied himself at his work, King crossed the river to Galena where he found a fellow Virginian, Andrew Keesecker, an accomplished printer, who agreed to return with King to Dubuque. It is interesting to note that, to Keesecker belongs the credit for setting the type and running the press for the first Iowa newspaper.

Jones relinquished his interest in the newspaper on $\mathrm{Au}$ gust 31 , when he found his political opinions adverse to a large majority of the citizens of Dubuque and could no longer conceal his strong feelings for the Jacksonian administration. King continued the paper until Dec. 31, 1836, when he announced its sale to William W. Chapman, a Burlington lawyer. Soon afterward Chapman was appointed prosecuting attorney by the Governor of Michigan Territory. Chapman knew that 
ownership of a newspaper was a powerful instrument in the hands of any politically ambitious man and he took the DuBuque Visitor when the opportunity was presented. He promised to avoid "personal" altercation and keep the paper free from everything savoring of "defamation and scurrility," pledging himself to boost Dubuque and the Iowa District. He failed to maintain the non-partisan attitude of his predecessor and gave his support to Andrew Jackson. His loyalty to the cause of democracy was soon rewarded by his appointment as attorney for the Territory of Wisconsin.

When Chapman took his new office, the newspaper fell into the hands of its third and last owner, William $\mathrm{H}$. Turner. Turner continued publication until May 17, 1837, when the first volume of 52 issues was completed. The paper was sold to John King, John B. Russell, and William Coriell. Apparently no issue appeared the following Wednesday; but Saturday, June 3, 1837, the first issue of the Iowa News appeared.

Throughout its existence, the Visitor was the only newspaper in the Black Hawk Purchase. Although its subscribers and advertisers could hardly appreciate its contemporary importance, the old files of the newspaper in the State Historical Building, Des Moines, form an important source of Iowa history.

\section{Burlington Gets a Paper}

Burlington had become the new capitol of the Territory of Wisconsin in 1837. The decision to move the capitol from Belmont, Wis., to the frontier town of Burlington was more a matter of expediency. For all its disadvantages, Burlington was located on the Mississippi River, and in a somewhat milder climate than Belmont. When the delegates arrived at the new capitol they found a settlement of rude cabins, a few brick buildings, and about 300 inhabitants. The same expediency which had brought the capitol to Burlington had motivated James Clarke and Cyrus Jacobs to move there.

As official printers for the Territory of Wisconsin, they packed up the presses, type, and paper stock, which had been used for the Belmont Gazette and migrated southward. On July 10, 1837, they published the first issue of the Wisconsin Territorial Gazette and Burlington Advertiser. At first, Jacobs 
was "the man with the pencil," while Clarke did the printing. However, Jacobs died less than half a year after the first Burlington issue of the Gazette and Clarke took over the editorship. Jacobs' death in November, 1937, climaxed a quarrel with attorney David Rorer; angered by political charges, Jacobs attempted to cane Rorer and was shot-as the coroner said -in self defense.

While Clarke published the official printing for the Territory, a neighboring newsman was having difficulties. It came apparent to James G. Edwards, who was editing the Fort Madison Patriot, that the territorial capitol offered more promise as a site for his paper and he cautiously offered the Burlington Patriot to would-be patrons on Dec. 13, 1838. Edwards apparently did not lock horns with Clarke at once, but waited until June 6,1839 , to begin continuous publication. The Patriot continued advocating the Whig cause and decrying the influence of liquor, until Sept. 5, 1839, when Edwards changed the name of his paper to the Hawk-Eye and Iowa Patriot.

Political discussions filled most of the columns of their early newspapers. Edwards lashed the policies of the territorial land office when it was operated by Democrats, while Clarke defended the territorial administration as well as President Van Buren.

Clarke had changed the name of his newspaper to the Iowa Territorial Gazette and Burlington Advertiser in July, 1838 , and promised that it would not be a "partizan newspaper." He broke this pledge when the rival editors became ingrossed in the election campaign that resulted in a Whig victory. John $\mathrm{H}$. McKenny had become Clarke's partner on the newspaper before the 1840 campaign. While they termed William Henry Harrison's platformless campaign the "great pageant of the log cabin," Van Buren and "Locofocism" were denounced by Edwards. A Whig parade through Burlington was mocked by the Gazette; "the editor of the Hawk-Eye, as usual, played Mr. Monkey to the caravan of Whiggery that was exhibited here on the 6th."

While politics and the territorial statutes occupied many columns, other items supplied readers with news of steamboat 
landings, recipes, advice on crops, and the "latest foreign intelligence," a term used for stories taken from eastern newspapers sometimes several months old.

McKenny acquired Clarke's interest in the Gazette in late 1840, and continued the Democratic tone of the newspaper when the territorial capitol was removed to Iowa City. In the summer of 1842, Bernhart Henn and James Morgan became joint editors and publishers of the Gazette. Henn later moved to Fairfield and was elected to Congress in 1850 and 1852. Morgan held a seat in the state legislature.

Clarke resumed editorship a year later in the midst of a bitter campaign for delegate to Congress which ended in the election of Augustus C. Dodge. For his loyalty and support to the Democratic party. Clarke was appointed Territorial Governor in November, 1845, serving until Dec. 3, 1846, when Ansel Briggs was inaugurated first Governor of the state.

The coming of statehood on Dec. 28, 1846, was hailed by both newspapers as a fortunate event. Amidst other changes, the Gazette became the Iowa State Gazette. Other events -the war with Mexico, the Texas question and the settlement of Oregon-also left their mark on the community. It seemed that a new order was about to take over when the first telegraphic news dispatches reached the Burlington Hawk-Eye in August, 1848.

During the cholera epidemic in 1850, James Clarke was one of the first victims. Edwards died during another outbreak of cholera in 1854. Dr. Philip Harvey became editor in 1851 and for several years the paper was one of the foremost supporters of the Democratic party in Iowa. The guiding genius of the Hawk-Eye for a time was Clark Dunham, who opposed the Democrats at every opportunity, helped foster the Republican party, and laid the Whig party to rest, convinced that the new group which nominated John C. Fremont for President in 1856 was destined for triumph.

The Hawk-Eye survived the panic of 1857, but the Iowa Daily State Gazette failed April 10, 1859. Early in 1862, G. M. Todd and A. P. Bentley revived the Gazette as the Argus. The editors changed their masthead frequently and for the next five years the paper was known as the Argus and the Gazette and Argus. In 1867, Richard Barrett and Charles I. Barker 
took over the Gazette, Barrett leaving within a short time. The Hawk-Eye Gazette staff was reorganized in 1874 and Robert J. Burdette became a member. His humor appealed to readers everywhere and the Hawk-Eye Gazette achieved nationwide circulation. In 1877, Burdette began a lecture tour across the nation. He was known as the "Hawk-Eye man" and continued to send letters known as "Robert's Ramblings" to the newspaper after he left Burlington in 1880.

\section{James G. Edwards}

Having been solicited to commence the publication of a newspaper in Fort Madison, James G. Edwards issued a prospectus on Nov. 28, 1837, in order to "ascertain as nearly as possible the amount of patronage that might be relied upon." $\mathrm{He}$ was confident that the resources of the Iowa community and the enterprising character of its inhabitants justified such a venture. Although two papers, both Democratic, were already established in the western part of Wisconsin Territory, the need of a Whig paper seemed apparent.

Edwards had arrived in Jacksonville, Ill., from Boston, in the fall of 1829. Inspired by the word of the missionaries and stimulated by an intense pietism, he established the Western Observer, intended to promote religion, crusade in the temperance cause, and sponsor the Whig party. The first number of the paper was published Jan. 24, 1830. In December, 1831, he changed the title to the Illinois Patriot. Printers would not stay with him, subscribers did not pay in cash, and a politician sued him for libel. He sold the newspaper and moved to Fort Madison where he purchased the printing equipment of Dr. Isaac Galland.

The first issue of the Fort Madison Patriot came from the press March 24, 1838, "before the admiring eyes of Chief Black Hawk and other Indians who frequently came to the office to inspect the mechanical part of the plant."

Edwards found the life of an editor here was no more prosperous or happy than it had been in Jacksonville. On Sept. 1, 1838, he loaded the printing press, type, and his household goods on a river boat, and set out for Burlington. the seat of government. Two months later, he published a specimen copy of the Burlington Patriot which he hoped would at- 
tract subscribers, but it died upon the day of its birth, and constituted the fourth newspaper that he had started in the West. Finally, following eight unsuccessful years, fortune smiled upon him.

On June 6, 1839, appeared the first number of the Iowa Patriot, the parent of the Burlington Hawk-Eye. In 1845, Edwards was again sued for libel and an article reflecting upon the motives for the election of Augustus C. Dodge to Congress in 1840 , provoked a street brawl with Dodge.

Dogmatic in politics and a fanatic in religion, Edwards lived an uneasy life, and his friends had difficulty in understanding some of his actions. He denounced the Mexican War, editorially thumbed his nose at the Democratic party, hated the Catholics, and despised the Mormons; yet, he had ability, was sincere, honest and pious, and he became the most vital editor of early Iowa.

\section{James and Richard Clarkson}

Most prominent among Iowa editors after the Civil War were James S. Clarkson and Richard P. Clarkson. Richard had come to Des Moines in 1861 and had been employed as a printer on the Iowa State Register. The paper then was edited by Frank W. Palmer, who changed the Register from a weekly to a daily in 1862 . Palmer had been with the Dubuque Times until he was elected State printer in 1860. James ("Ret") Clarkson came to Des Moines in 1866 and "Father" Clarkson followed in 1870 when the Clarksons bought the Register from J. W. and F. M. Mills. They had been farming in Grundy County, Iowa, before that. "Father" had been a veteran editor of the Brookville American in Indiana.

The Clarksons were exciting newspapermen. individuals of stron opinions who did not hesitate to express themselves. Intensely Republican, they regarded all Democrats as allies of the rebels of 1861-65. For 32 years the family supported the cause of Iowa and Iowa farmers.

In 1872, a row broke out in the family. "Father" was a personal friend of Iowa Senator James Harlan and spared no words to the effect that he would support the Senator. The sons favored William B. Allison, who was Harlan's of ponent for re-election to the U. S. Senate. "Father" thumped on the 


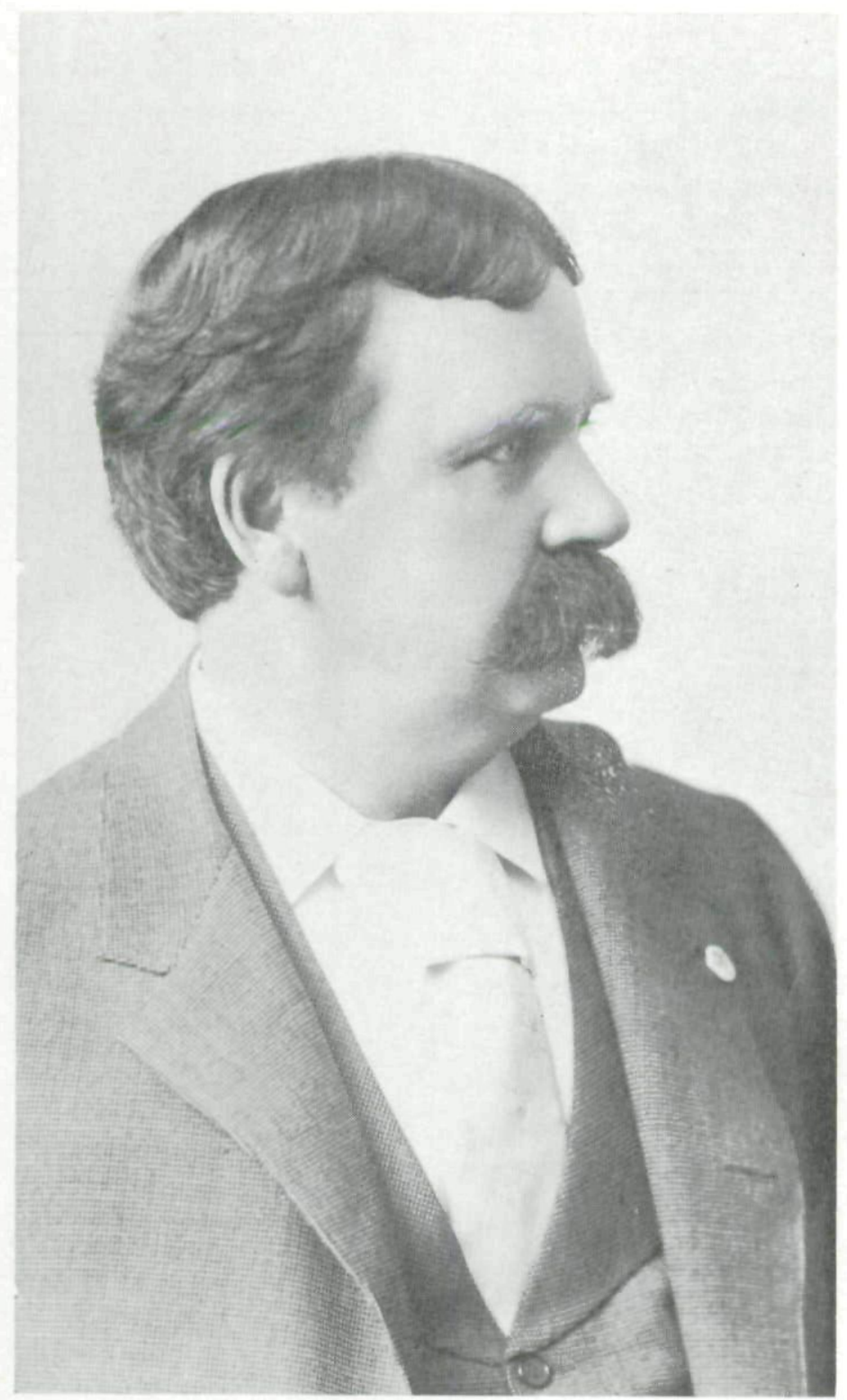

James S. Clarkson 
desk and declared that as long as he owned any part of the paper, Harlan would be given its support. Ora Williams, former Iowa Curator of History, told what happened then.

"Father" was asked to name his price for his one-third interest. Knowing his sons had no bank account, he said he would take $\$ 30,000$. "Ret" made a trip to Dubuque and, after an interview with Jacob Rich, came back and laid $\$ 30,000$ on the table. After that, the elder Clarkson was just the farm editor. The paper supported Allison and he was elected. Harlan later privately charged that Allison had furnished $\$ 5,000$ to help "Ret" swing the deal.

"Ret" wrote his own copy and had the reputation for being able to write three-fourths of the paper in one evening. He was known far and wide by his nickname which originated in his custom of marking his copy with "Ret. Clarkson" (Return to Clarkson) so that all his editorials and articles, dashed off in an illegible handwriting, would be returned to him for proofreading before going to press. The printers shied at his copy and the tradition is that a strike resulted from its illegibility, the outcome being an agreement to pay the printers who set the type from his copy "price and a half." So it came about that those who familiarized themselves with Clarkson's writing, his copy was "phat."

It was related among printers that one time a deaf and dumb printer who was also a musician, was observed one day loitering at his type case. When the foreman inquired why he was not working, the printer dejectedly pointed his stick at the copy.

"Can't you read it?" wrote the foreman.

"Read it!" wrote the printer. "Read nothing; but if I had my flute here I could play it."

The Clarksons' most important contributions to Iowa journalism were in the fields of state news and farm news. They covered such varied subjects as elections, church and school news and crime news. Their paper became the Bible of Radical Republicanism in Iowa and much of the Middle West.

In 1885, they announced: "From this time on, the Register will be made the daily as well as the weekly paper of the enterprising and intelligent citizens of every city, town and neighborhood in the state. We shall strive to be still more an 
Iowa paper, putting our own state first in all our efforts and bending our strength to service in every good way."

"Father" Clarkson deserved much of the credit for the development of the Register into a major state paper. In his column, "Farm, Garden and Orchard," he scolded farmers for going into debt and for using bad farming practices; he advised them how to increase their yields and how to combat crop and animal diseases.

The Clarkson era ended at the close of the 19th century. "Father" Clarkson had died in 1890; "Ret" had early become a national figure in the Republican party, was chairman of the National Republican Executive Committee from 1890 to 1892, and in that same period, was named First Assistant Postmaster General. He sold his half interest in the newspaper to his brother in 1891 and moved to the East where, on April 17, 1902, he was appointed Surveyor of the Port of New York. Although no longer a resident of Iowa, he never lost interest in the state, nor in the paper he had made famous.

\section{Andrew Logan}

The first issue of the Iowa Sun, a six-column, four-page newspaper, was published at Davenport on Aug. 4, 1838. The editor, Andrew Logan, had arrived on July 7, from Pennsylvania, and set out at once to find a location for his shop. He found a place on Water Street, upstairs in Mr. Davenport's "new building" and announced that the paper would be published every Saturday morning.

Logan promised in his prospectus to maintain political freedom and to "freely keep the columns of the Iowa Sun open to all temperate and well written communications from all parties." He pledged the paper's support to the administration of the Territorial government and declared that the Iowa Sun would print abstracts of Congressional and Territorial legislation. He planned to furnish subscribers with factual material concerning the country along the Mississippi River, original tales, and poetry.

This ambitious prospectus established a difficult goal to obtain. The press was old, the type well-worn, and there were limited facilities for gathering news. Logan's only assistants were his two small sons, the elder of whom was but 12 years old. 
The first issue brought favorable comments. The editor of the Gazette at Burlington wrote that he hoped the Iowa Sun would shine steadily and brightly, and after each weekly setting rise again with renewed brightness. Logan might well be called a one man chamber of commerce, for he devoted much space in nearly every issue to publicizing the "Queen City" and the surrounding countryside.

After Davenport became the county seat, Logan campaigned to have the Territorial capitol located there. The Iowa Sun was an interesting and informative paper, containing important legislative acts, poetry, messages to Congress, Presidential decrees, fiction, essays, and foreign news. Learning of Great Britain's acquisition of the Falkland Islands in 1833 , in order "to protect the seal fisheries," Logan wrote, "We suppose John will land a force on Nantucket ere long and issue a similar order."

On one occasion Logan described a visit to some of the farms near Davenport when he "saw many beets that would measure from 20 to 30 inches long and from 14 to 18 inches in circumference." His enthusiasm for Scott County produce led him to be badly "sold" once by a practical joker. The fellow stuck half a dozen potatoes together with pegs. Logan viewed the "phenomenal" vegetable, "defying any other soil under the sun to produce its equal." Upon discovering the hoax sometime later, he was quite embarassed and, it is said, did not puff any mammoth vegetables for three whole weeks.

Among human interest stories, Logan wrote of an account of a "mermaid" captured off the coast of northern Ireland. When he ran short of news, Logan resorted to fillers to complete the paper. In one issue he wrote: a woman "was so large when she died, that her friends had to go twice to her funeral."

In spite of a constant struggle to gather news, collect delinquent accounts and to keep the ancient press running, the paper seemed to flourish for a while. When the Davenport Weekly Gazette began publication, Logan decided to quit and the Iowa Sun was discontinued in 1842. Logan sold the press and type to some Mormons who intended to publish a newspaper at Buffalo, Scott County, and he began farming six 
miles west of Davenport on the Iowa City road.

Logan's efforts to "develop the boundless resources of the territory and to invite to our soil, moral, industrious, and intelligent cultivators" did not go unappreciated by the citizens of rapidly growing Davenport. It is written that "he has always been a good friend to the interests of Scott County, ever carrying with him the goodwill, respect, and esteem of all who have had the pleasure of his acquaintance."

Pioneer journalism continued in the state until the late 1870 's. The pioneer editor, who with printers' ink and paper, had chronicled the unfolding of a civilization in an area that was wilderness when he first arrived, and the itinerant printer with his "shirt-tail full of type" had become more settled and more permanent in residence. The files of old newspapers of early day Iowa bring those bygone years back to life more vividly than rewritten history can ever do.

\section{MUSEUM NOTES}

\section{Lights from the Dim, Dark Past}

Until the invention of the electric lamp, shortly before the turn of the century, man's basic lighting techniques had remained practically unchanged for thousands of years. In rural areas the oil lamp was still in general use less than 40 years ago. Now, with our fast-moving society, we seldom give thought to anything so commonplace as electricity. Only when we experience a power failure do we realize the convenience of our modern methods of lighting.

A new museum exhibit, Lights from the Dim, Dark Past, shows basic lighting techniques from the 17 and 1800 's. Included in the exhibit are several "Betty" lamps from 1700; a candle mold; block matches; oil lamps, including a lard oil lamp; oil and candle holders; and an electric lamp from 1890. This exhibit is located on the second floor of the Museum. 
Copyright of Annals of Iowa is the property of State of Iowa, by \& through the State Historical Society of Iowa and its content may not be copied or emailed to multiple sites or posted to a listserv without the copyright holder's express written permission. However, users may print, download, or email articles for individual use. 